\title{
Floristic composition, phytosociology and weed diversity in chives (Allium schoenoprasum L.)
}

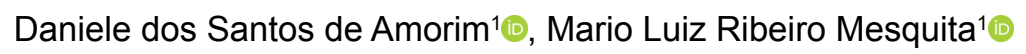 \\ ${ }^{1}$ Universidade Estadual do Maranhão, Campus Bacabal, Departamento de Ciências Agrárias, Bacabal, MA, Brazil. E-mail: daniele.amorim1010@gmail.com; mario-mesquita51@hotmail.com
}

ABSTRACT: Assessment of floristic composition, phytosociology and diversity of weed communities are crucial for weed control in chives. A survey was conducted on two selected chives cropping fields in the state of Maranhão, northeastern Brazil to identify the weed flora and the most important weed species associated with chives. The weed survey was carried out by the quadrat method with 30 weed samples taken from each chives field. Phytosociological parameters assessed were absolute and relative densities, frequencies and abundances and the importance value of each species. Weed diversity was assessed by the Shannon Diversity Index $\left(H^{\prime}\right)$. We recorded a total of 3,689 individuals from 36 species and 16 families. The two families with the highest species richness were Poaceae $(n=7)$ and Cyperaceae $(n=5)$. The greater number of species $(30)$ was recorded in the chives grown in Catucá. The most important species based on the importance value were Hediotys corimbosa, Schoenoplectus juncoides and Ludwigia octovalvis, in Areal and Eleusine indica, Trianthema portulacastrum and Cyperus iria in Catucá. Floristic diversity was higher in Areal $\left(H^{\prime}=5.21\right.$ nats. ind $\left.{ }^{-1}\right)$. These results could lead to improved weed management strategies in chives croppping in the state of Maranhão, northeastern Brazil.

\section{Composição florística, fitossociologia e diversidade de plantas daninhas no cultivo da cebolinha (Allium schoenoprasum L.)}

RESUMO: Avaliação da composição florística, da fitossociologia e da diversidade de comunidades de plantas daninhas são cruciais para o controle dessas espécies no cultivo de cebolinha. Um levantamento foi realizado em dois campos cultivados com cebolinha no estado do Maranhão. $O$ objetivo foi identificar a flora de plantas daninhas e as espécies mais importantes associadas à cebolinha. 0 levantamento foi realizado pelo método quadrado inventário com 30 amostras em cada campo de cebolinha. Os parâmetros fitossociológicos avaliados foram a densidade, a frequência, a abundância e o valor de importância de cada espécie. A diversidade florística foi avaliada pelo Índice de Diversidade de Shannon. Foram registrados 3.689 indivíduos de 36 espécies e 16 famílias. As duas famílias com maior riqueza de espécies foram Poaceae $(n=7)$ e Cyperaceae $(n=5)$. Catucá teve o maior número de espécies (30). As espécies mais importantes baseadas no valor de importância foram Hediotys corymbosa, Schoenoplectus juncoides e Ludwigia octovalvis, em Areal e Eleusine indica, Trianthema portulacastrum e Cyperus iria em Catucá. A diversidade florística foi maior em Areal $\left(H^{\prime}=5.21\right.$ nats. ind $\left.^{-1}\right)$. Estes resultados podem contribuir para melhorar o manejo de plantas daninhas no cultivo de cebolinha no estado do Maranhão, nordeste do Brasil. 


\section{Introduction}

Chives (Allium schoenoprasum L.), Alliaceae, from European origin, is a seasoning leafy vegetable with cylindrical, fistulous (hollow), aromatic leaves and inflorescences of the umbel type, with purplish-colored flowers. It is a perennial species that can reach 30 to $50 \mathrm{~cm}$ in height and reproduces both by seeds and by tillers produced by the adult plant (Heredia Zárate et al., 2003).

Experimental studies have shown that chives has health benefits (Hanen et al. 2002). Moreover, it is a rich source of antioxidants (Štagner et al. 2011; Xavier et al. 2011), has antimicrobial properties (Sharifi-Rad et al. 2016) and produces phenolic compounds with antiproliferative and tumor arresting effects (Kucekova et al. 2016).

Due to the plant architecture being cylindrical with erect leaves, chives cannot shade the soil. This means that there are enough spaces in the soil for germination, establishment and growth of weeds that interfere with the crop growth and development. Thus, weeds are a major biological constraint limiting chives yield.

Weeds negatively affect chives cropping by competition for water, nutrients, space and light and by allelopathy, that is, the production and release of toxic substances that inhibit germination and growth of other species associated with them. Moreover, many weed species are intermediate hosts of pests and diseases (Silva et al., 2006).

According to Pereira \& Melo (2008), weed incidence in vegetable crops varies depending on the species, particularly with respect to the vegetable plant architecture and different plant spacings, among other factors. It is generally accepted that vegetable crops that shades the soil grow with little interference from weeds.

Weed surveys, associated with phytosociological studies and assessment of floristic diversity, are important to understand the weed community structure and crucial to subsidize weed management practices in chives cultivation.

Floristic and phytosociological surveys of weeds have already been carried out in several vegetable crops, including tomato (Lycopersicum esculentum Mill.) (Correa, 2015), okra (Abelmoschus esculentus Moench) (Bachega et al., 2013; Santos et al., 2017), turnip (Brassica napus L.), lettuce (Lactuca sativa L.), sweet potato [Ipomoea batatas (L.) Lam.] (Raya et al., 2013), and watermelon [Citrullus lanatus (Thunb.) Matsum. \& Nakai] (Maciel et al., 2008), but there is no report on weed floristic and phytosociological surveys on chives yet.

Chives cultivation has great expressiveness in northeastern Brazil, particularly in the state of Maranhão. Data on the geographical distribution of vegetable production show that, in relation to the number of establishments that grow vegetables in Maranhão, chives occupies the third position, with 1,998 establishments after West Indian gherkin (Cucumis anguria L.) with 3,788 establishments and green maize (Zea mays L.), with 3,487 establishments (Embrapa, 2016). However, there are no reports on the occurrence of weeds in chives in this region.
In this context, the objectives of this research were to carry out floristic and phytosociological surveys, to compute phytosociological parameters and to assess the floristic diversity of the weed community in chives cultivation in the state of Maranhão, northeastern Brazil.

\section{Material and Methods}

\section{Study site}

This research was carried out in Areal (4'14"12,2 "S and

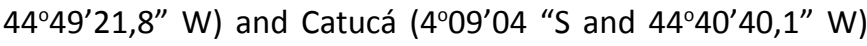
villages, located $50 \mathrm{~km}$ way from each other in the municipality of Bacabal, in the central portion of the state of Maranhão, northeastern Brazil.

The climate of the region is Aw, according to the classification of Köppen, a tropical climate, hot and humid with one rainy season that extends from January to June and a dry one, from July to December. In the rainy season, the average rainfall reaches about $1,558.86 \mathrm{~mm}$ and in the dry season, it is around $166.00 \mathrm{~mm}$ (Silva et al., 2016). The average temperature is $25^{\circ} \mathrm{C}$.

The relief is flat and smooth wavy. The altitude is approximately 38 meters. It can be noticed the presence of residual hills in some stretches. These forms were modeled in the siltites, argillites and sometimes clayey sandstones and shales that are part of the lithology of the Itapecuru Formation. Soils of the study sites are classified as Plintosols with clayey texture in Catucá and Latosols, with sandy texture in Areal (IBGE, 1997; Embrapa, 2006).

Vegetation in the two sites is classified as open ombrophylous forest with Babaçu (Orbignya phalerata Mart.) Arecaceae, secondary forest fallow regrowth, which had suffered frequent previous slash-and-burn cycles of agriculture (Gehring et al. 2011).

According to information from the local farmers, Areal has been cultivated with chives for about 20 years and Catucá for 35 years.

\section{Description of the chives cropping system}

The most traditional chives cultivar planted in the two sites is "Todo Ano", which hails from Europe and has leaves of light green color. It is considered a perennial species, with cylindrical and fistulous leaves, height ranging from 0,30 to $0,50 \mathrm{~m}$, that also produces small conical bulb, surrounded by a rosy film, with tillering and clump formation (Heredia Zárate et al., 2003).

Chives are vegetatively propagated. Seedlings are harvested, cleaned and are prepared a day before planting. Roots and dried sheaths are removed and leaves are cut to leave five $\mathrm{cm}$ bulblets. Seedlings are then planted, leaving about four $\mathrm{cm}$ of the bulblets uncovered.

Chives planting is done with spacing varying from 20 to $40 \mathrm{~cm}$ between rows and 15 to $30 \mathrm{~cm}$ between plants within rows in manually prepared beds, with approximately 10 meters long, one meter wide and $30 \mathrm{~cm}$ high made by family farmers organized in community associations. 
The basic fertilization is done with cattle manure, in the dose of $20 \mathrm{~kg} \mathrm{~m}^{-2}$ of bed. Plants are watered daily using surface irrigation. Weeds are controlled by hoeing between rows and hand weeding within the row once or twice a month, depending on the level of infestation. Pest control is done occasionally and the occurrence of diseases is usually not controlled. Chives with all healthy leaves longer than 15 $\mathrm{cm}$, are harvested at 50 days after planting by cutting leaves at the soil level.

\section{Floristic survey and weed species identification}

The weed flora was sampled 25 days after planting, just before the first weeding in order to identify as many species as possible and consequently to evaluate the floristic diversity before the species were controlled by the farmers. Field work was done on May 11th 2016 in Areal and on May 13th 2016 in Catucá villages by randomly launching a $1.0 \mathrm{~m} \times 1.0 \mathrm{~m}$ metal quadrat 30 times on the beds planted with chives in each site. The total planted area with chives in each site was $3,000 \mathrm{~m}^{2}$. Thus the total sampled area was $30 \mathrm{~m}^{2}$ for each site.

The weeds that remained in the perimeter of the quadrat were cut close to the ground, identified, separated by species and counted. The data were organized in spreadsheets by inputting the scientific name of each species and the respective botanical family. Species were identified by means of comparisons with other species already identified in the literature and also by consulting experts.

The floristic list with families and species was organized according to the classification system established in the Angiosperm Phylogeny Group IV guidelines (APG IV, 2016). All scientific names and their authors were confirmed after verification in the International Plant Names Index (IPNI, 2017).

\section{Computation of phytosociological parameters}

The number of individuals of each species identified in the floristic survey served as basis for computing the following phytosociological parameters: absolute and relative frequencies, absolute and relative densities, absolute and relative abundances, and the importance value of each species (Muller-Dombois \& Ellemberg, 1974).

Although all the absolute and relative values of the phytosociological parameters were computed, we presented and discussed only the relative data, in percentage.

The phytosociological parameters were computed using the following Equations 1, 2, 3, 4, 5, 6 and 7.

$$
\mathrm{AFi}=\frac{\mathrm{NSi}}{\mathrm{TNS}}
$$

where: $\mathrm{AFi}=$ absolute frequency of the species $\mathrm{i} ; \mathrm{NSi}=$ number of samples with the presence of the species $\mathrm{i}$; TNS = total number of samples.

$$
\mathrm{RFi}=\frac{\mathrm{AFi}}{\sum \mathrm{AF}} \times 100
$$

where: $\mathrm{RFi}=$ relative frequency of the species $\mathrm{i} ; \mathrm{AFi}=$ absolute frequency of the species $i ; \sum A F=$ sum of all absolute frequencies.

$$
\mathrm{ADi}=\frac{\mathrm{TNi}}{\mathrm{A}}
$$

where: $A D i=$ absolute density of the species $\mathrm{i} ; \mathrm{TNi}=$ total number of individuals of the species $\mathrm{i} ; \mathrm{A}=$ area sampled in hectares.

$$
\mathrm{RDi}=\frac{\mathrm{ADi}}{\sum \mathrm{AD}} \times 100
$$

where: $\mathrm{RDi}=$ relative density of the species $\mathrm{i} ; \mathrm{ADi}=$ absolute density of the species $\mathrm{i} ; \Sigma A D=$ Sum of all absolute densities.

$$
\mathrm{AAi}=\frac{\mathrm{TNi}}{\mathrm{TNSi}}
$$

where: $\mathrm{AAi}=$ absolute abundance of the species $\mathrm{i} ; \mathrm{TNi}=$ total number of individuals of the species $\mathrm{i}$; TNSi $=$ total number of samples with the presence of the species $i$.

$$
\mathrm{RAi}=\frac{\mathrm{AAi}}{\sum \mathrm{AA}} \times 100
$$

where: $\mathrm{RA} i=$ relative abundance of the species $\mathrm{i} ; \mathrm{AAi}=$ absolute abundance of the species $i ; \Sigma A A=$ Sum of all absolute abundances.

$$
\mathrm{IVi}=\mathrm{RFi}+\mathrm{RDi}+\mathrm{RAi}
$$

where: $\mathrm{IVi}=$ importance value of the species $\mathrm{i}$; $\mathrm{RFi}=$ relative frequency of the species $\mathrm{i} ; \mathrm{RDi}=$ relative density of the species $\mathrm{i} ; \mathrm{RA} \mathrm{i}=$ relative abundance of the species $\mathrm{i}$.

\section{Assessment of floristic diversity}

Floristic diversity of each site was assessed by the Shannon Diversity Index $\left(H^{\prime}\right)$ based on natural logarithm, which considers equal weight among rare and abundant species. It is considered that the higher the value of $H^{\prime}$ the greater the floristic diversity will be (Shannon \& Weaver, 1949). The Shannon Diversity Index was computed by the Equation 8.

$$
\mathrm{H}=-\sum_{\mathrm{I}=1}^{\mathrm{S}} \text { pilnpi }
$$

where: In is the natural logarithm; $\mathrm{pi}=\mathrm{ni} / \mathrm{N}$; $\mathrm{ni}$ is the number of sampled individuals of the species $\mathrm{i}$; and $\mathrm{N}$ is the total number of sampled individuals. The result is expressed in natural digits (nats) per individual, because the formula uses a log base e. It varies from 1.5 to 3.5 and hardly exceeds 4.0 (Kwak \& Peterson, 2007). 


\section{Results and Discussion}

We recorded 16 families with 36 species represented by 3,689 individuals (Table 1). The largest number of individuals, $2,160(58.6 \%)$ was recorded in chives grown in the Areal village.

The two families that had the highest species richness were Poaceae $(n=7)$ and Cyperaceae $(n=5)$. These families collectively accounted for $33 \%$ of the species sampled in the weed floristic composition of the two sites (Figure 1).

Qian et al. (2008) also reported similar results, with the Poaceae family as the most representative in a weed survey carried out on chives in Xanghai, composing $20 \%$ of the sampled species.

Research results with other vegetables, such as cowpea, [Vigna unguiculata (L.) Walp.] carried out by Marques et al. (2010) in the state of Maranhão and a phytosociological survey of weeds carried out in lowland tomatoes (Lycopersicum esculentum Mill.) grown in the states of Goiás, Minas Gerais

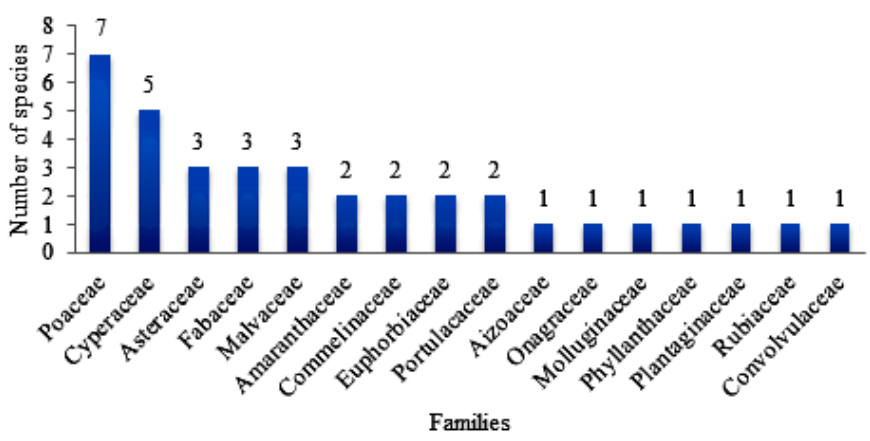

Figure 1. Floristic composition of the weed community in chives grown in Areal and Catucá villages, in the municipality of Bacabal, state of Maranhão, northeastern Brazil.

and São Paulo, by Correa (2015), showed that Cyperaceae and Poaceae were the more representative families in relation to species richness.

Moreover, Raya et al. (2013) in floristic weed survey on vegetables such as turnip (Brassica napus L.), lettuce (Lactuca

Table 1. List of species, families and number of individuals of weeds in chives grown in Areal and Catucá villages in the municipality of Bacabal, state of Maranhão, northeastern Brazil.

\begin{tabular}{|c|c|c|c|}
\hline \multirow{2}{*}{ Species } & \multirow{2}{*}{ Family } & \multicolumn{2}{|c|}{ Number of individuals } \\
\hline & & Areal & Catucá \\
\hline Trianthema portulacastrum $\mathrm{L}$. & AIZOACEAE & 4 & 262 \\
\hline Amaranthus lividus L. & AMARANTHACEAE & 17 & 39 \\
\hline Amaranthus retroflexus $\mathrm{L}$. & AMARANTHACEAE & 1 & ---- \\
\hline Eclipta prostata $\mathrm{L}$. & ASTERACEAE & 1 & -.-- \\
\hline Emilia coccinea (Sims) G. Don & ASTERACEAE & --- & 1 \\
\hline Emilia sonchifolia (L.) DC & ASTERACEAE & ---- & 34 \\
\hline Commelina benghalensis $\mathrm{L}$. & COMMELINACEAE & 34 & 11 \\
\hline Murdannia nudiflora (L.) Brenan & COMMELINACEAE & 22 & 105 \\
\hline Ipomoea triloba $\mathrm{L}$. & CONVOLVULACEAE & ---- & 1 \\
\hline Cyperus aggregatus (Willd.) Endl. & CYPERACEAE & ---- & 1 \\
\hline Cyperus iria L. & CYPERACEAE & 96 & 150 \\
\hline Fimbristylis miliacea (L.) Vahl & CYPERACEAE & 3 & 5 \\
\hline Pycreus lanceolatus C. B. Clarke & CYPERACEAE & 48 & ---- \\
\hline Schoenoplectus juncoides (Roxb.) Palla & CYPERACEAE & 425 & 12 \\
\hline Chamaesyce hirta (L.) Millsp. & EUPHORBIACEAE & 161 & 104 \\
\hline Chamaesyce prostrata (Aiton) Small & EUPHORBIACEAE & 87 & 3 \\
\hline Crotalaria incana $\mathrm{L}$. & FABACEAE & 8 & ---- \\
\hline Crotalaria spectabilis Roth & FABACEAE & ---- & 1 \\
\hline Desmodium adscendens (Sw.) DC. & FABACEAE & ---- & 6 \\
\hline Sida cordifolia L. & MALVACEAE & 3 & ---- \\
\hline Sida glaziovii K. Schum & MALVACEAE & 7 & 20 \\
\hline Sida rhombifolia $\mathrm{L}$. & MALVACEAE & ---- & 7 \\
\hline Mollugo verticillata $\mathrm{L}$. & MOLLUGINACEAE & 3 & ---- \\
\hline Ludwigia octovalvis (Jacq.) P.H. Raven & ONAGRACEAE & 233 & 2 \\
\hline Phyllanthus niruri L. & PHYLLANTHACEAE & 65 & 7 \\
\hline Lindernia crustacea (L.) f. Muell & PLANTAGINACEAE & 126 & 70 \\
\hline Cenchrus echinatus L. & POACEAE & 3 & 33 \\
\hline Cynodon dactylon (L.) Pers. & POACEAE & -.-- & 1 \\
\hline Digitaria sanguinalis (L.) Scop. & POACEAE & 8 & 38 \\
\hline Echinochloa colona (L.) Link & POACEAE & ---- & 24 \\
\hline Eleusine indica (L.) Gaertn & POACEAE & 44 & 451 \\
\hline Paspalum distichum $\mathrm{L}$. & POACEAE & ---- & 1 \\
\hline Sporobulus indicus (L.) R. Br. & POACEAE & 124 & 11 \\
\hline Portulaca oleracea $\mathrm{L}$. & PORTULACACEAE & 34 & 101 \\
\hline Talinum paniculatum (Jacq.) Gaertn. & PORTULACACEAE & 2 & 2 \\
\hline Hedyotis corymbosa (L.) Lam & RUBIACEAE & 601 & 26 \\
\hline
\end{tabular}


sativa L.) and sweet potato [Ipomoea batatas (L.) Lam.] in Malaysia also reported that these botanical families accounted for $43 \%$ of the sampled weed species.

In one hand, Poaceae family species richness is related to the way most of their species grow with dense clumps or the presence of rhizomateous and stolonipherous individuals widely scattered in the weed community. This is considered a major feature of the dominance of this family in many cropping fields (Munhoz \& Felfili, 2006).

On the other hand, Cyperaceae family species richness reflects the competitive advantage, that is, the ability of vegetative propagation through a complex underground system consisting of rhizomes and tubers with many species having underground stolons (Munhoz \& Felfili, 2006). In addition to this, formation of a significant seed bank is an important regeneration component for many species of this family (Leck \& Schütz, 2005; Mesquita et al., 2013).

The greatest number of species was recorded in Catucá ( $n$ $=30)$, and the lowest in Areal $(n=27)$, however, the weed density was higher in Areal, with 180 plants. $\mathrm{m}^{-2}$ against 127 plants. $\mathrm{m}^{-2}$ in Catucá. Differences in the number of weed species and weed density are due to the history of the areas and weed management adopted by the farmers; Catucá, for example, is under chives cultivation for a longer time (35 years) than Areal (20 years), therefore the weed community is higher in Catucá. Although weed control practices by hoeing between rows and hand weeding within rows are similar in both sites, data of weed density indicates that weed control is more efficient in Catucá where weed density was $29 \%$ lower than in Areal.

Of the 36 species recorded in this study, 20 (56\%), were common to the two sites: T. portulacastrum, A. lividus, $C$. benghalensis, M. nudiflora, C. iria, F. miliacea, S. juncoides, C. hirta, C. prostrata, S. glaziovii, L. octovalvis, P. niruri, $L$. crustacea, C. echinatus, D. sanguinalis, E. indica, S. indicus, $P$. oleracea, $T$. paniculatum and $H$. corymbosa. This indicates that they have not only great plasticity, that is, the capacity to adapt to different sites, but also tolerance to stress imposed by the weed control methods used by the farmers.
In contrast, six species were recorded only at Areal: A. retroflexus, E. prostrata, P. lanceolatus, C. incana, $M$. verticilata and $S$. cordifolia, and 10 species were found only at Catucá: E. coccinea, E. sonchifolia, I. triloba, C. aggregatus, C. spectabilis, $D$. adscendens, S. rhombifolia, $C$. dactylon, $E$. colona and $P$. distichum.

The occurrence pattern of herbaceous plants such as weeds in space is heterogenous and complex. Climate variables and different microhabitat conditions in the soil can act as regulators of populations in the herbaceous community, reflecting in the variations of birth and mortality rates, and in density, favoring the emergence of certain exclusive species in a given habitat (Araújo et al., 2005; Silva et al., 2016).

On the other hand, Munhoz \& Felfili (2006), observed that some species may have different establishment strategies in time and space. In addition, differences in weed species occurrence in cropping fields may be related to the history of the areas and the crop management practices.

The predominant weed species in chives cultivation in the Areal village, considering the Importance Value (IV), in decreasing order, were Hedyotis corymbosa, (IV $=55.96 \%$ ), Schoenoplectus juncoides (IV $=42.43 \%$ ) and Ludwigia octovalvis (IV = 27.21\%). In contrast, in Catucá village, the most important weed species were Eleusine indica (IV $=54.77 \%$ ) Trianthema portulacastrum, (IV $=36.39 \%$ ) and Cyperus iria, (IV $=24.65 \%$ ).

The phytosociological parameters that most contributed to the Importance Value of the abovementioned species in both sites were the Relative Density and Relative Abundance, indicating that these species had the populations with greater participation in the weed community not only in numerical terms but also in the distribution of individuals in the chives cropping fields investigated, except for L. octovalvis in Areal and C. iria in Catuca where the Relative Density and Relative Frequency were the most important parameters in the composition of the Importance Value (Table 2).

The differences between the species of greater Importance Value in the two sites with the highest incidence of $E$. indica in the village of Catucá is probably because the soil where the

Table 2. Phytosociological parameters of weed communities with the ten species that stood out with the highest Importance Value in areas cultivated with chives at Areal and Catucá villages in the municipality of Bacabal, state of Maranhão, northeastern Brazil.

\begin{tabular}{lccccccccc}
\hline & \multicolumn{1}{c}{ Site } \\
\hline \multicolumn{1}{c}{ Areal } \\
\multicolumn{1}{c}{ Species } & RF & RD & RA & IV\% & Species & RF & RD & RA & IV\% \\
\hline Hedyotis corymbosa & 9.03 & 27.75 & 19.18 & 55.96 & Eleusine indica & 11.22 & 29.50 & 14.05 & 54.77 \\
Schoenoplectus juncoides & 8.74 & 19.65 & 14.04 & 42.43 & Trianthema portulacastrum & 8.35 & 17.14 & 11.02 & 36.39 \\
Ludwigia octovalvis & 8.74 & 10.77 & 7.70 & 27.21 & Cyperus iria & 9.10 & 9.81 & 5.74 & 24.65 \\
Chamaesyce hirta & 6.20 & 7.44 & 7.45 & 21.09 & Chamaesyce hirta & 9.60 & 6.80 & 3.80 & 20.20 \\
Lindernia crustacea & 7.15 & 5.83 & 5.07 & 18.05 & Mudannia nudiflora & 5.36 & 6.87 & 6.80 & 19.03 \\
Sporobolus indicus & 5.93 & 5.73 & 6.04 & 17.7 & Portulaca oleracea & 7.48 & 6.61 & 4.72 & 18.81 \\
Cyperus iria & 7.15 & 4.44 & 3.86 & 15.45 & Lindernia crustacea & 4.99 & 4.58 & 4.90 & 14.47 \\
Chamaesyce prostrata & 4.70 & 4.02 & 5.37 & 14.09 & Amaranthus lividus & 6.61 & 2.55 & 2.04 & 11.20 \\
Phyllanthus niruri & 6.58 & 3.00 & 2.87 & 12.45 & Cenchrus echinatus & 1.62 & 2.16 & 6.94 & 10.72 \\
Pycreus lanceolatus & 4.70 & 2.22 & 2.96 & 9.88 & Sporobulus indicus & 0.37 & 0.72 & 9.25 & 10.34 \\
\hline
\end{tabular}

$\mathrm{RF}=$ Relative Frequency, $\mathrm{RD}=$ Relative Density, $\mathrm{RA}=$ Relative Abundance, IV = Importance Value. 
chives are planted in this village is of clayey texture and more compacted (data not shown). Lorenzi (2008) states that the occurrence of $E$. indica in compacted soils is higher because it has a well-developed fasciculate root system that grows better in more densely soils. Moreover, E. indica produces allelopathic compounds, which inhibit the growth and development of other plants including vegetables.

The highest floristic diversity according to the Shannon Diversity Index was observed in Areal $\left(H^{\prime}=5.21\right)$, versus $\left(H^{\prime}\right.$ $=4.92$ ) in Catucá. Both indices are higher than that obtained by Kostrzewska et al. (2014) in research carried out with pea (Pisum sativum L.) in Poland $\left(H^{\prime}=0.8\right)$ and Chikoye et al. (2003), in green corn (Zea mays L.) grown in Nigeria $\left(H^{\prime}=2.20\right)$ indicating the existence of greater weed floristic diversity in chives grown in the state of Maranhão. This is probably due to favorable climatic conditions for weed growth, especially the amount and regular distribution of rainfall during the rainy season.

\section{Conclusions}

The floristic composition of weeds varied between chives cultivation in Areal and Catucá villages in the state of Maranhão, northeastern Brazil. The highest floristic richness was recorded in Areal village, with 30 species of 16 botanical families. The two families with higher species richness are Poaceae and Cyperaceae,

The five most important species in chives cultivation in Areal village in decreasing order of Importance Value are Hedyotis corymbosa Schoenoplectus juncoides Ludwigia octovalvis Chamaesyce hirta and Lindernia crustacea whereas in Catucá, the most important are Eleusine indica, Trianthema portulacastrum, Cyperus iria, Chamaesyce hirta and Murdannia nudiflora.

The floristic diversity of weeds varied between chives cultivation in Areal and Catucá villages in the state of Maranhão, northeastern Brazil. The highest diversity was observed in Areal.

These results could lead to improved weed management strategies in chives cropping in the state of Maranhão, northeastern Brazil.

\section{Literature Cited}

Angiosperm Phylogeny Group - APG. An update of the Angiosperm Phylogeny Group classification for the orders and families of flowering plants: APG IV. Botanical Journal of the Linnean Society, v.181, n.1, p.1-20, 2016. https://doi.org/10.1111/boj.12385.

Araújo, E. L.; Silva, K. A.; Ferraz, E. M. N.; Sampaio E.V.S. B.; Silva, S. I. Diversidade de herbáceas em microhabitats rochoso, plano e ciliar em uma área de caatinga, Caruaru, PE, Brasil. Acta Botanica Brasilica, v.19, n.2, p.285-294, 2005. https://doi.org/10.1590/ S0102-33062005000200011.

Bachega, L.P.S.; Carvalho, L.B.; Bianco, S.; Cecílio Filho, A.B. Períodos de interferência de plantas daninhas na cultura do quiabo, Planta daninha, v.31, n.1, p.63-70, 2013. https://doi.org/10.1590/ s0100-83582013000100007.
Chikoye, D.; Schulz, S.; Ekeleme, F. Evaluation of integrated weed management practices for maize in the northern Guinea savanna of Nigeria. Crop Protection, v.23, n.10, p.895-900, 2013. https:// doi.org/10.1016/j.cropro.2004.01.013.

Correa, N. M. Levantamento fitossociológico de plantas daninhas em áreas de produção de tomate rasteiro dos estados de GO, MG e SP. Brasília, DF: Embrapa Hortaliças, 2015. 52p. (Embrapa Hortaliças. Documentos, 147). http://ainfo.cnptia.embrapa.br/ digital/bitstream/item/133449/1/DOC-147X.pdf. 27 Abr. 2018.

Empresa Brasileira de Pesquisa Agropecuária - Embrapa. Hortaliças em números. 2016. http://www.cnph.embrapa.br/paginas/ hortalicas_em_numeros/hortalicas_em_numeros.htm. 07 Jun. 2017.

Empresa Brasileira de Pesquisa Agropecuária - Embrapa. Sistema brasileiro de classificação de solos. 2.ed. Rio de Janeiro: Embrapa, 2006. 306p. https://vdocuments.site/sistema-brasileiro-declassificacao-dos-solos2006pdf.html. 03 Abr. 2018.

Gehring, C.; Zelarayán, M. L. C.; Almeida, R. B.; Moraes, F. H. R. Allometry of the babassu palm growing on a slash-and-burn agroecosystem of the eastern periphery of Amazonia, Acta Amazonica, v. 41, n. 1, p. 127-134, 2011. https://doi.org/10.1590/ S0044-59672011000100015.

Hanen, N.; Fattouch, S. E.; Ammar, E.; Neffati, M. Allium species, ancient health food for the future? In: Valdez, B. (Ed.). Scientific, health and social aspects of the food industry. London: InTechOpen, 2012. Chap. 17, p.343-354. https://www. intechopen.com/books/scientific-health-and-social-aspects-ofthe-food-industry/allium-species-ancient-health-food-for-thefuture-. 14 Jun 2017.

Heredia Zárate, N.A.; Vieira, M.C.; Bratti, R. Efeitos da cama-defrangos e da época de colheita sobre a produção e a renda bruta da cebolinha 'Todo Ano'. Pesquisa Agropecuária Tropical, v.33, n.2, p.73-78, 2003. https://www.revistas.ufg.br/pat/article/ view/2350/2333. 13 Nov 2018.

Instituto Brasileiro de Geografia e Estatística - IBGF. Zoneamento geoambiental do Estado do Maranhão, diretrizes gerais para ordenamento territorial. Salvador: IBGE, 1997. 44p. https:// biblioteca.ibge.gov.br/visualizacao/livros/liv95885.pdf. 02 Mai. 2018

International Plant Names Index - INPI. Search Plant Names. Plant Name Query. http://www.ipni.org/ipni/plantnamesearchpage. do. 10 Dez. 2017.

Kostrzewska, M. K.; Jastrzębska, M.; Treder, K.; Wanic, M. diversity of segetal weeds in pea (Pisum sativum L.) depending on crops chosen for a crop rotation system. Acta Agrobotanica, v. 67, n. 1, p. 55-66, 2014. https://doi.org/10.5586/aa.2014.008.

Kucekova, Z.; Mlcek, J.; Humpolicek, P.; Rop, O.; Valasek, P.; Saha. P. Molecules, v. 16, n.1, p.9207-9217, 2011. https://doi. org/10.3390/molecules16119207.

Kwak, T.J.; Peterson J.T. Community indices, parameters, and comparisons. In: Guy; C. S.; Brown, M. L. (Eds.). Analysis and interpretation of freshwater fisheries data. Bethesda: American Fisheries Society, 2007. p.677-763. https://repository.lib.ncsu. edu/bitstream/handle/1840.2/483/Kwak_\%26_Peterson_2007. pdf?sequence=1\&isAllowed=y. 09 Mai. 2018. 
Leck, M.A.; Schütz, W. Regeneration of Cyperaceae, with particular reference to seed ecology and seed banks. Perspectives in Plant Ecology, Evolution and Systematics, v.7, n.2, p.95-133, 2005. https://doi.org/10.1016/j.ppees.2005.05.001.

Lorenzi, H. Plantas daninhas do Brasil: terrestres, aquáticas, parasitas e toxicas. 4.ed. Nova Odessa: Instituto Plantarum, 2008. 640p.

Maciel, C. D. G.; Poletine, J. P.; Velini, E. D.; Belisário, D. R. S.; Martins, F. M.; Alves, L. S. Interferência de plantas daninhas no cultivo de melancia. Horticultura Brasileira, v.26, n.1, p.107-111, 2008. https://doi.org/10.1590/S0102-05362008000100021.

Marques, L.J.P.; Silva. M.R.M.; Araújo, M.S.; Lopes, G.S.; Corrêa, M.J.P.; Freitas, A.C.R.; Muniz, F.H. Composição florística de plantas daninhas na cultura do feijão-caupi no sistema de capoeira triturada. Planta Daninha, v. 28, n.spe., p.953-961, 2010. https:// doi.org/10.1590/S0100-83582010000500003.

Mesquita, M. L. R.; Andrade, L. A.; Pereira, W. E. Floristic diversity of the soil weed seed bank in a rice growing area of Brazil: in situ and ex situ evaluation. Acta Botanica Brasilica, v.27, n.3, p.465-471, 2013. https://doi.org/10.1590/S0102-33062013000300001.

Muller-Dombois, D.; Ellemberg, H. Aims and methods of vegetation ecology. New York: John Wiley \& Sons, 1974. 547p.

Munhoz, C.B.R.; Felfili, J.M. Fitossociologia do estrato herbáceosubarbustivo de uma área de campo sujo no Distrito Federal, Brasil. Acta Botanica Brasilica, v.20, n.3, p. 671-685. 2006. https:// doi.org/10.1590/S010233062006000300017.

Pereira, W.; Melo, W. F. Manejo das plantas espontâneas no sistema de produção orgânica de hortaliças. Brasília: Embrapa Hortaliças, 2008. 5p. (Embrapa Hortaliças. Circular Técnica, 62). https://www. embrapa.br/en/busca-de-publicacoes/-/publicacao/780759/ manejo-de-plantas-espontaneas-no-sistema-de-producaoorganica-de-hortalicas. 24 Set. 2018.

Qian Z.; Shen G.; Li T.; Chai X. Study on the occurrence and control of weeds in Allium schoenoprasum field. Acta Agriculturae Shanghai, v.1, p.81-84, 2008. http://caod.oriprobe.com/articles/13775970/ Study_on_the_occurrence_and_control_of_weeds_in_Allium_ schoenoprasum_f.htm. 30 Jan. 2018.
Raya, K. B.; Ahmed, S. H.; Juraimi, A. S.; Bakar, R. A.; Uddin M. K. Floristic composition of weed community in selected vegetable fields in Selangor, Malaysia. Journal of Food, Agriculture and Environment. v. 11, n.3-4, p.1659-1663, 2013. https://www. researchgate.net/publication/302025339. 26 Mar. 2018.

Santos, R. N. V.; Rodrigues, A. A. C.; Silva, M. R. M. Correa, M. J. P.; Mesquita. M. L R. Phytosociology and weed interference in okra under organic cropping system. African Journal of Agricultural Research, v. 12, n. 4, p.251-259, 2017. https://doi.org/10.5897/ AJAR2016.11888.

Shannon, C.E.; Weaver, W. The mathematical theory of communication. Urbana: University of Illinois Press, 1949. 132p. http://www.magmamater.cl/MatheComm.pdf. 22 Jun. 2018.

Sharifi-Rad, J.; Mnayer, D.; Tabanelli, G.; Stojanović-Radić, Z. Z.; Sharifi-Rad, M.; Yousaf, Z.; Vallone L.; Setzer, W. N.; Iriti, M. Plants of the genus Allium as antibacterial agents: From tradition to pharmacy. Cellular and Molecular Biology, v. 62, n. 9, p. 7-68. 2016. https://doi.org/10.14715/cmb/2016.62.9.10.

Silva, A. C.; Ferreira, F. A.; Ferreira, L. R. Manejo integrado de plantas daninhas em hortaliças. Pesquisa \& Tecnologia, v. 3, n. 2, p. 1-7, 2006. http://www.aptaregional.sp.gov.br/acesse-os-artigospesquisa-e-tecnologia/edicao-2006/2006-julho-dezembro/456manejo-integrado-de-plantas-daninhas-em-hortalicas/file. html?force_download=1. 27 Nov. 2017.

Silva, K. A.; Santos, J. M. F. F.; Andrade, J. R.; Lima, E. N.; Albuquerque U. P.; Ferraz E. M. N.; Araújo E. L. The influence of microhabitat on the population dynamics of four herbaceous species in a semiarid area of northeastern Brazil. Brazilian Journal of Biology, v. 76, n. 1, p. 45-54, 2016. https://doi.org/10.1590/1519-6984.10014.

Štagner, D.; Popovic, B. M.; Calic-Dragosavac, D.; Malenčic, D.; Zdravkovic-Korac, S. Comparative study on Allium schoenoprasum cultivated plant and Allium schoenoprasum tissue culture organs antioxidant status. Phytotherapy Research, v.25, n.11, p. 16181622, 2011. https://doi.org/10.1002/ptr.3394.

Xavier, J. R.; Bajpai, P. K.; Muthiah, P. M.; Dhar, P.; Kumar, J.; Chaurasia, O. M.; Srivastava, R. B.; Singh, S. B. Trans-Himalayan phytofoods - A rich source of antioxidants. Journal of Medicinal and Aromatic Plant Sciences, v. 33, n. 1, p.21-26, 2011. https:// www.researchgate.net/publication/232041891. 12 Jul. 2018. 